\title{
Transcriptional Responses of the Heat Shock Protein 20 (Hsp20) and 40 (Hsp40) Genes to Temperature Stress and Alteration of Life Cycle Stages in the Harmful Alga Scrippsiella trochoidea (Dinophyceae)
}

\author{
Yunyan Deng ${ }^{1,2,3,+} \mathbb{C}$, Zhangxi $\mathrm{Hu}{ }^{1,2,3,+} \oplus$, Lixia Shang ${ }^{1,2,3}$, Zhaoyang Chai ${ }^{1,2,3}$ and \\ Ying Zhong Tang ${ }^{1,2,3, *(D)}$ \\ 1 CAS Key Laboratory of Marine Ecology and Environmental Sciences, Institute of Oceanology, \\ Chinese Academy of Sciences, Qingdao 266071, China; yunyandeng@qdio.ac.cn (Y.D.); \\ zhu@qdio.ac.cn (Z.H.); lxshang@qdio.ac.cn (L.S.); zhaoyangchai@qdio.ac.cn (Z.C.) \\ 2 Laboratory of Marine Ecology and Environmental Science, Qingdao National Laboratory for Marine Science \\ and Technology, Qingdao 266237, China \\ 3 Center for Ocean Mega-Science, Chinese Academy of Sciences, Qingdao 266071, China \\ * Correspondence: yingzhong.tang@qdio.ac.cn; Tel./Fax: +86-532-8289-6098 \\ $\dagger$ These authors had equal contributions to the work.
}

Received: 27 October 2020; Accepted: 18 November 2020; Published: 21 November 2020

check for updates

Simple Summary: As the greatest contributors to harmful algal blooms, dinoflagellates account for roughly $75 \%$ of bloom events, which become an escalating threat to coastal ecosystems and cause substantial economic loss worldwide. Resting cyst production and broad temperature tolerance are well proven as adaptive strategies for blooming dinoflagellates; however, to date, the underlying molecular information is scarce. In the present study, we characterized two heat shock protein genes from the representative dinoflagellate Scrippsiella trochoidea, with the aim to primarily determine their possible roles in response to temperature stress and alteration of the life cycle. The yielded results enhance our knowledge about the functions of cross-talk of different Hsp members in temperature adaptation of dinoflagellates and facilitate further exploration in their potential physiological relevance during different life-stage alternation in this ecological important lineage.

\begin{abstract}
The small heat shock protein (sHsp) and Hsp40 are Hsp members that have not been intensively investigated but are functionally important in most organisms. In this study, the potential roles of a Hsp2O (StHsp20) and a Hsp40 (StHsp40) in dinoflagellates during adaptation to temperature fluctuation and alteration of different life stages were explored using the representative harmful algal blooms (HABs)-causative dinoflagellate species, Scrippsiella trochoidea. We isolated the full-length cDNAs of the two genes via rapid amplification of cDNA ends (RACE) and tracked their differential transcriptions via real-time qPCR. The results revealed StHsp20 and StHsp40 exhibited mRNA accumulation patterns that were highly similar in response to heat stress but completely different toward cold stress, which implies that the mechanisms underlying thermal and cold acclimation in dinoflagellates are regulated by different sets of genes. The StHsp20 was probably related to the heat tolerance of the species, and StHsp 40 was closely involved in the adaptation to both higher and lower temperature fluctuations. Furthermore, significantly higher mRNA abundance of StHsp 40 was detected in newly formed resting cysts, which might be a response to intrinsic stress stemmed from encystment. This finding also implied StHsp 40 might be engaged in resting cyst formation of S. trochoidea. Our findings enriched the knowledge about possible cross-talk of different Hsp members in dinoflagellates and provided clues to further explore the molecular underpinnings underlying resting cyst production and broad temperature tolerance of this group of HABs contributors.
\end{abstract}


Keywords: Scrippsiella trochoidea; resting cyst; dinoflagellate; harmful algal blooms; heat shock protein 20 (Hsp20); heat shock protein 40 (Hsp40); temperature stress

\section{Introduction}

Dinoflagellates are ubiquitous unicellular microalgae, which occupy vital niches in marine and freshwater environments [1]. Many members in this lineage have major ecological and economic impacts, among which the most notorious is resulting in harmful algal blooms (HABs) [1,2]. So far, approximately 200 species of dinoflagellates have been recorded to be able to cause HABs, accounting for roughly $75 \%$ of $\mathrm{HAB}$ events [3]. The ecological success of dinoflagellates under certain circumstances at least partly stems from their multiple ecological strategies and functional traits [4,5]. Some dinoflagellate species have a life-history strategy that includes a dormant stage in their life cycles, called resting cyst. Different lines of evidence prove that such cysts play an important role in the ecology of dinoflagellates, especially in those HABs-causative members, as they have been demonstrated to be associated with protecting cells from adverse environments, genetic recombination, seeding and terminating HABs, and geographic expansion of populations [5-12]. Additionally, some HABs-causative dinoflagellates are eurythermal species, which display wide tolerance to temperature fluctuations [13-16]. Several case studies have demonstrated that broad temperature tolerance contributed to population survival, distribution expansion, and even bloom formation of these species [15-17]. Despite the ecological importance of resting cyst production and broad temperature tolerance as ecological strategies for HABs-causative dinoflagellates, we currently have a poor understanding of their underlying genetic basis, such as the functional genes and the detailed molecular mechanisms involved, in large part owing to extremely larger and more complex genomes of dinoflagellates and relatively little attention paid to these facets.

Heat shock proteins (Hsps) are vital cellular chaperones, which function as central components in homeostasis maintenance under both favorable and unfavorable conditions and in coping with a variety of stresses [18,19]. The small Hsps (sHsps), which are a group of Hsps with molecular weights of 12-43 kDa, include an $\alpha$-crystalline domain (ACD) and variable C- and N-terminal extensions $[19,20]$. Their monomers could aggregate into a large oligomer of approximately $200-800 \mathrm{kDa}$, which is essential for their function in aggregation prevention and new protein refolding [20,21]. The sHsp family probably contains the most diverse members in structure and function among various families of stress responsive proteins [22]. Their abundance and heterogeneity imply their unique and multiple functions [23]. Apart from stress resistance [24,25], sHsps have been proven to engage in a variety of physiological processes, including embryogenesis and cell proliferation [26-28], insect development [29], actin and intermediate filament dynamics [30,31], life span [32], membrane fluidity [33], and disease prevention [34-36]. The Hsp40s, characteristic with the presence of a J-domain, were initially identified to be capable of stimulating the ATPase activity of DnaK (the Hsp70 homolog in bacteria) and helping replicate phage DNA in host cells [37,38]. Until now, members in the Hsp40 family have been verified to play critical roles in a series of cellular protein processing, such as translation, folding, unfolding, translocation, and degradation [39-42]. As an important co-chaperonin of Hsp70s, Hsp40 recognizes unfolded substrates and delivers them to Hsp70, which in turn, leads to a conformational change in Hsp70 that stabilizes its binding to the substrates [39,43]. Many environmental cues, such as temperature and drought, are stimuli for Hsp40s production, and therefore, they are considered to be common cellular stress sensors and relevant to stress resistance [42,44,45]. Meanwhile, members of Hsp40s are also implicated in many aspects of Hsp70s functions, such as signal transduction, fungal growth, plant development, and various human diseases [39,42,46-48].

In dinoflagellates, Hsp-related investigations have progressed primarily from those on Hsp70 and Hsp90 families. Information about sHsps and Hsp40s is relatively scanty and fragmentary, as it mainly comes from omics-based resources without further structural and functional verification. Differential 
transcription levels were documented for Hsp 20 and Hsp 40 members in a Symbiodinium species subjected to thermal stress $[49,50]$. One Hsp20 gene was once detected from Karenia mikimotoi and proposed to be involved in cell proliferation [51]. One DnaJ (Hsp40) chaperone homolog in Prorocentrum donghaiense was observed to be greatly upregulated upon dissolved inorganic phosphorus limitation [52]. DnaJ homologs were also recorded to display higher protein abundance in toxin-producing strains of dinoflagellate Alexandrium catenella than those in its non-toxic mutant, suggesting these homologs were involved in an adaptive response to active toxin biosynthesis in A. catenella [53]. Therefore, whether or not and how sHsp and Hsp40 in dinoflagellates are responding to temperature stress, as their names imply, remains to be important questions to be answered.

The dinoflagellate Scrippsiella trochoidea is an eurythermal (with a temperature tolerance range of $10-30{ }^{\circ} \mathrm{C}$ ), cosmopolitan, HAB-forming, and toxic dinoflagellate [13,54,55]. Due to readily producing resting cysts, this species has been adopted as representative species for life history studies on dinoflagellates [56-60]. In the present work, the potential roles of a Hsp20 (StHsp20) and a Hsp40 (StHsp40) from S. trochoidea during adaptation to temperature fluctuation and alteration of different life stages were preliminarily investigated based on full-length cDNA isolation. The yielded results will enhance our knowledge about functions of Hsp members in dinoflagellates and facilitate further exploration of their possible ecological relevance in this lineage.

\section{Materials and Methods}

\subsection{Scrippsiella trochoidea Culture Maintenance}

The strain IOCAS-St-1 of Scrippsiella trochoidea originally isolated from the Yellow Sea of China was obtained from the Marine Biological Culture Collection Centre, Institute of Oceanology, Chinese Academy of Sciences and confirmed by rDNA sequencing [57]. The $\mathrm{f} / 2$ medium without silica [61] added with PII metal mix of GSe medium [62] and a penicillin-streptomycin solution (100×, Solarbio, Beijing, China) (final concentration of $2 \%$ ) was made with autoclaved and sterile $0.22 \mu \mathrm{m}$ filtered natural seawater with a salinity of 32-33. Cells used for culture maintenance were incubated at $20 \pm 1{ }^{\circ} \mathrm{C}$ under $100 \mu \mathrm{mol}$ photons $\mathrm{m}^{-2} \mathrm{~s}^{-1}$ provided with a light: dark cycle of $12: 12 \mathrm{~h}$, using cool white fluorescent light.

\subsection{Full-Length cDNAs Cloning of StHsp20 and StHsp40}

For cDNA cloning, about $10^{6}$ fresh vegetative cells at the exponential growth stage from the regular cultures were harvested by centrifugation and used for total RNA extraction. Total RNA was isolated according to Deng et al. (2019) [58] and digested with RNase-Free DNase Set (QIAGEN, Hilden, Germany) following manufacture instruction. The concentration and quality of total RNA was determined by agarose gel electrophoresis and NanoDrop ${ }^{\mathrm{TM}} 1000$ spectrophotometer (Thermo Fisher Scientific, Waltham, MA, USA).

For fragments amplifications, single-strand cDNAs synthesized from $\sim 1 \mu \mathrm{g}$ total RNA with random primers using Reverse Transcriptase M-MLV (Takara, Tokyo, Japan) were used as templates. Two pairs of specific primers, 20-F and 20-R and 40-F and 40-R (Table 1), were designed based on Hsp20-like and Hsp40-like sequences, respectively, found in previous transcriptome of S. trochoidea (GenBank accession no. SRP058465; [57]) for amplifying cDNA fragments following the protocol described before [63]. To isolate the full-length cDNAs of the two genes, rapid amplification of cDNA ends (RACE) PCR were performed as described previously $[58,63]$. The obtained cDNA sequences from fragments amplifications were used to design gene-specific primers (Table 1) for $5^{\prime}$ and $3^{\prime}$ RACE, respectively. The first strand cDNAs prepared from $\sim 1 \mu \mathrm{g}$ total RNA with the anchor primer $[58,63]$ were used as the templates in RACEs. In the $5^{\prime}$ RACEs, PCR was performed with forward primer DinoSL (specific to dinoflagellates; [64,65]) coupled with reverse primers 5r-20-outer and 5r-20-inner and 5r-40-outer and 5r-40-inner (Table 1). For the $3^{\prime}$ ends, PCR were run with the forward primers, 3r-20-outer and 3r-20-inner and 3r-40-outer and 3r-40-inner (Table 1), paired with 
reverse primer GeneRacer3 (Invitrogen, Karlsruhe, Germany). All final products were confirmed by agarose gel electrophoresis, purified, respectively, with Generay DNA fragment recovery kit (Shanghai, China), cloned into T-vector as reported [59] and then sequenced at the Sangon Biotech Company (Qingdao, China).

Table 1. Primers details.

\begin{tabular}{|c|c|c|}
\hline Primer Name & Nucleotide Sequences $\left(5^{\prime} \rightarrow 3^{\prime}\right)$ & Amplicon Length \\
\hline $40-\mathrm{F}$ & GGCGAGGAAGACTTCTATCAGG & \multirow{2}{*}{$587 \mathrm{bp}$} \\
\hline $40-\mathrm{R}$ & TGCTGCGTCTGCATCACG & \\
\hline 5r-40-outer & CAATCTGCTGGAACTTGTCCTGCG & $496 \mathrm{bp}$ \\
\hline 5r-40-inner & GCGGACTTGATTTCCCTGTCGTTG & $416 \mathrm{bp}$ \\
\hline $3 r-40$-outer & AGTGGACCTCCССTTCAAAACCG & $830 \mathrm{bp}$ \\
\hline 3r-40-inner & ССACСССTCTGGGCGTGATGC & $670 \mathrm{bp}$ \\
\hline $20-\mathrm{F}$ & СССТTСТTCGССТTCAАСС & \multirow{2}{*}{$216 \mathrm{bp}$} \\
\hline $20-\mathrm{R}$ & TTCTGTGGAGCGCTTGG & \\
\hline 5r-20-outer & GCTTCAAGGTGCCGTTCTCCA & $417 \mathrm{bp}$ \\
\hline 5r-20-inner & CGTGGCGGCGGGACTTGG & $306 \mathrm{bp}$ \\
\hline 3r-20-outer & CGACATCATTGAAAGAGACGACGCC & $750 \mathrm{bp}$ \\
\hline 3r-20-inner & TTCACTCGAGGTGGAGAACGGCA & $680 \mathrm{bp}$ \\
\hline q40-F & GCATCAAGTGCGAGGGTAGG & \multirow{2}{*}{$124 \mathrm{bp}$} \\
\hline q40-R & TGCTGCGTCTGCATCACG & \\
\hline q20-F & TGGAGAACGGCACCTTGAA & \multirow{2}{*}{$183 \mathrm{bp}$} \\
\hline q20-R & TGGGCAGAGTGATGGTGAGC & \\
\hline
\end{tabular}

\subsection{Sequence Analysis of StHsp20 and StHsp 40}

The generated full-length nucleotide sequences of StHsp2O and StHsp40 were analyzed with the ORF Finder program [66] and NCBI BLAST programs [67]. The molecular weights and theoretical isoelectric points were predicted using ProtParam software [68]. The secondary structures were identified with the SOPMA program [69]. The signal peptides and transmembrane topological structures were checked with SignalP 5.0 Server and TMHMM Server programs, respectively $[70,71]$.

\subsection{Samples Collection}

\subsubsection{Temperature Stresses Exposure Treatments}

To observe the transcriptional response of StHsp20 and StHsp40 exposed to temperature fluctuations, vegetative cells (approximately $1.5 \times 10^{4}$ cells $\mathrm{mL}^{-1}$ ) grown at routine maintenance conditions $\left(20 \pm 1{ }^{\circ} \mathrm{C}\right)$ were aliquoted into culture plates (6-well; Corning, Corning, NY, USA). Temperature treatments of 3 scenarios were performed as described before $[58,60]$ and briefed as follows: in the first assay, cells that were maintained at $20^{\circ} \mathrm{C}$ were withdrawn and immediately treated with higher or lower temperature $\left(30,25,20,15\right.$, and $\left.5^{\circ} \mathrm{C}\right)$ for $60 \mathrm{~min}$ in incubators with the temperature set in advance; in the second time-course assay, cells that were maintained at $20^{\circ} \mathrm{C}$ were exposed to 10 and $30^{\circ} \mathrm{C}$, respectively, for 0 (control; sampled at the start of exposure experiment), 3 , $5,10,15,20,30,60,120$, and $180 \mathrm{~min}$ in an incubator with pre-set temperatures; the last assay was conducted to compare the effects between a moderate and a drastic temperature stress. The drastic one was to expose the cultures directly to a temperature stress of $10{ }^{\circ} \mathrm{C}$ (i.e., from 20 to $30^{\circ} \mathrm{C}$ and from 20 to $10^{\circ} \mathrm{C}$, respectively) for $60 \mathrm{~min}$. While the moderate one was to expose the culture to a temperature stress of $5{ }^{\circ} \mathrm{C}$ for $10 \mathrm{~min}$ first and then expose to a further $5{ }^{\circ} \mathrm{C}$ change for $60 \mathrm{~min}$ (i.e., from 20 to $15^{\circ} \mathrm{C}$ 
or $25^{\circ} \mathrm{C}$ for $10 \mathrm{~min}$ and then to 10 or $30^{\circ} \mathrm{C}$ for $60 \mathrm{~min}$ ). For the abovementioned 3 assays, cultures kept at $20^{\circ} \mathrm{C}$ were treated as control, and all treatments were conducted independently in triplicate. After treatments, approximately $2 \times 10^{4}$ vegetative cells or resting cysts for each sample were harvested, immediately frozen in liquid nitrogen, and then kept at $-80^{\circ} \mathrm{C}$.

\subsubsection{Cells at Different Stages of Life Cycle}

To investigate transcriptional response of StHsp2O and StHsp 40 at different stages of the life cycle, vegetative cells and resting cysts were prepared, referring to the previous studies [58-60], and briefed below. For vegetative cells, $S$. trochoidea (initial cell density of $\sim 2 \times 10^{3}$ cells $\mathrm{mL}^{-1}$ ) was inoculated into $300 \mathrm{~mL}$ medium in $500 \mathrm{~mL}$ Pyrex flask. Cell density was determined via daily cell counting as described in Deng et al. (2019) [59]. The growth stages of vegetative cells were determined according to growth curve (see Supporting Information Figure S2 for more details). Vegetative cells $\left(\sim 2 \times 10^{4}\right.$ cells for each sample; 3 biological replicates) were harvested on day 5, 9 (exponential growth stage) and day 12,15 (stationary growth stage) (the day of inoculation was recorded as day 0 ) for qPCR gene analysis.

For resting cyst samples, including newly formed resting cysts, resting cysts maintained at $4{ }^{\circ} \mathrm{C}$ in darkness for 20 and 30 days, respectively, were produced according to Deng et al. (2019) [58] and briefed as follows. Vegetative cells grown in 6-well culture plates (Corning, Corning, NY, USA; $10 \mathrm{~mL}$ in each well) were used for resting cyst production. They were incubated at routine maintenance conditions except for that the medium was made with artificial seawater supplemented with all nutrients of the abovementioned recipe but nitrogen and phosphorus [58]. For the species, Scrippsiella trochoidea, there are clear distinctions in morphological features between vegetative cells and resting cysts (Supporting information Figure S1). Vegetative cells with their two flagella swam in the plates, while resting cysts without flagellum settled at the bottom, which allowed a swift judgement and separation via light microscopy (see [57] for more details). Cyst formation was checked every other day under inverted microscope (Olympus IX73). Resting cysts were generally obtained from the cultures that had been inoculated for about 20-30 days. They were cleaned with fresh sterile filtered seawater several times until no vegetative cell or planozygote (motile zygote) was observed under microscope. The obtained resting cysts (in 6-well culture plates) were then stored at $4 \pm 1{ }^{\circ} \mathrm{C}$ in darkness for 20 and 30 days, respectively. For each sample, approximately $2 \times 10^{4}$ vegetative cells or resting cysts ( 3 biological replicates) were harvested, immediately frozen in liquid nitrogen, and then kept at $-80^{\circ} \mathrm{C}$.

\subsection{Real-Time Quantitative PCR ( $q P C R$ )}

The qPCRs were performed on Bio-Rad CFX96 Real-Time PCR Detection System using Takara TB Green Premix Ex Taq ${ }^{\mathrm{TM}}$ II (Tokyo, Japan). The protocol and cycling conditions generally followed that described in [60]. Samples $\left(\sim 2 \times 10^{4}\right.$ cells or cysts for each sample; 3 biological replicates) prepared as described in 2.4 were used in qPCR detection. Total RNAs were extracted as mentioned above. For each sample, the first-strand cDNA synthesized from $\sim 60 \mathrm{ng}$ total RNA with random primers was used as template. The qPCR was performed in a volume of $20 \mu \mathrm{L}$, which contained $10.0 \mu \mathrm{L} 2 \times$ SYBR Premix (TaKaRa, Tokyo, Japan), $1 \mu \mathrm{L}$ template cDNA, $0.5 \mu \mathrm{L}$ of each primer $(10 \mu \mathrm{M})$, and $8.0 \mu \mathrm{L}$ RNase-free water. The cycling conditions were $95{ }^{\circ} \mathrm{C}$ for $30 \mathrm{~s}$, followed by 40 cycles of $94{ }^{\circ} \mathrm{C}$ for $5 \mathrm{~s}, 50{ }^{\circ} \mathrm{C}$ for $30 \mathrm{~s}$, and $72{ }^{\circ} \mathrm{C}$ for $30 \mathrm{~s}$. Two specific primer sets, q20-F and q20-R and q40-F and q40-R (Table 1), were used to amplify $183 \mathrm{bp}$ and $124 \mathrm{bp}$ products of $S t H s p 40$ and StHsp20, respectively. The combination of $U B Q$ (ubiquitin), UBC (ubiquitin conjugating enzyme), and $M D H$ (malate dehydrogenase) was used as internal control in the qPCR detection of cells exposure to temperature stresses [60]. The combination of $M D H, U B C$, and $L B P$ (luciferin-binding protein) was applied into qPCR analyses of genes transcription at different stages of the life cycle [57]. All qPCR products were sequenced to confirm correct amplifications. For each primer set, relative standard curve [72] and qPCR efficiency $(E)$ [73] were determined as previously described [58]. Relative quantitative values were calculated by the $2^{-\Delta \Delta \mathrm{Ct}}$ relative quantification method with qBasePlus software [74,75]. All reactions were performed in biological triplicates. The relative expression levels of targeted genes among different treatments were 
analyzed using one-way analysis of variance (ANOVA), with the significant level of $P$ set at 0.05 . All statistical tests were performed with SPSS 20.0 statistical software.

\section{Results}

\section{1. cDNA Cloning and Sequencing Characterization of StHsp20 and StHsp 40}

The full-length cDNA of StHsp20 was 1059 bp, comprising a 194 bp 5'-UTR with the canonical dinoflagellate spliced leader (DinoSL) sequence, a 433 bp 3'-UTR, and a 432 bp ORF (open reading frame) (GenBank accession no. MN698834). The StHsp20 ORF had 63\% G + C content and encoded 143 amino acids, with a predicted molecular weight of $16.09 \mathrm{kDa}$ and an isoelectric point of 9.39 . The results showed that the deduced amino acid sequence containing a characteristic $\alpha$-crystalline domain (ACD) spanned 88 amino acid residues (42-192 aa) (Figure 1). Twelve amino acid residues, including Asp42, Ile43, Ile44, Glu45, Arg46, Arg53, Ser55, Pro57, Gly58, Arg101, Gly121, and Val122, were predicted to compose the putative dimer interface in the ACD (Figure 1). No signal peptide was detected via the SignalP program. Moreover, the StHsp20 protein was predicted to present outside membrane and contain $25.17 \% \alpha$-helix, $18.88 \%$ extended strand, $8.39 \% \beta$-turn, and $47.55 \%$ random coil.

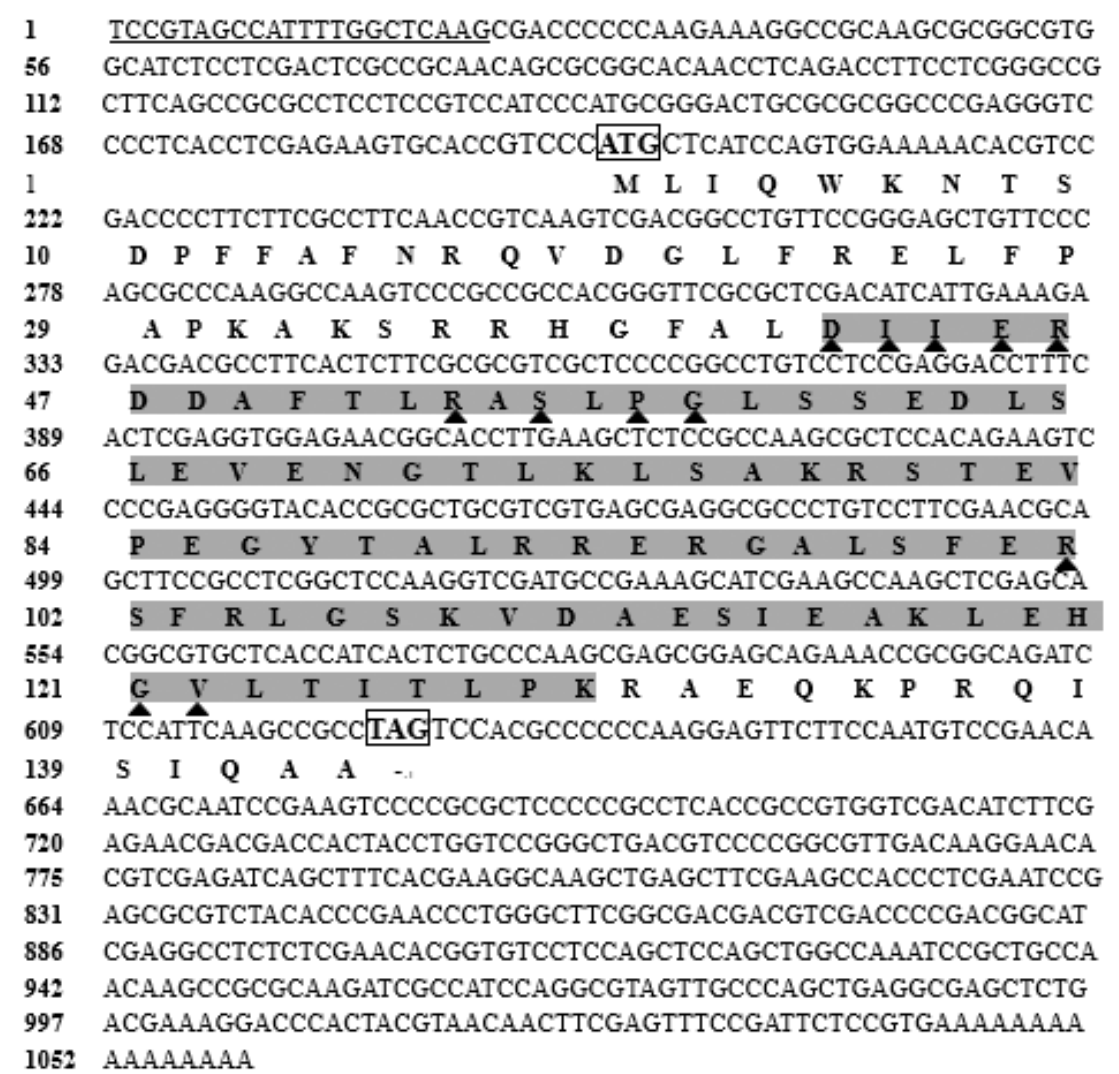

Figure 1. The cDNA and deduced amino acid sequences of StHsp20 (accession number: MN698834): the boxes for start and stop codons; underline for DinoSL; dark gray background for characteristic $\alpha$-crystalline domain (ACD); triangles for the putative dimer interfaces.

The assembled full-length StHsp40 (1564 bp; GenBank accession no. MN698835) covered a $112 \mathrm{bp}$ 3' UTR and a $72 \mathrm{bp} \mathrm{5} 5^{\prime}$ UTR with a conserved DinoSL sequence. The resultant $1380 \mathrm{bp}$ ORF with $66 \% \mathrm{G}+$ $\mathrm{C}$ content encoded a protein of 459 amino acids, with a predicted molecular weight of $49.22 \mathrm{kDa}$ and an isoelectric point of 9.58. The BLAST results showed that the StHsp40 protein included 3 characteristic domains: a classical J-domain (95-153 aa), a zinc-finger domain (154-312 aa) featured by four repeats of CxxCxGxG, and a C-terminal domain (313-442 aa) (Figure 2). The SignalP program analysis found 
no signal peptide in StHsp40. According to the transmembrane topological structure analysis using TMHMM Server program, StHsp40 was presumed to be outside membrane. Four conformational states, $27.45 \% \alpha$-helix, $18.52 \%$ extended strand, $7.19 \% \beta$-turn, and $46.84 \%$ random coil, were predicted in the secondary structure, suggesting that random coil is the major component of StHsp40.

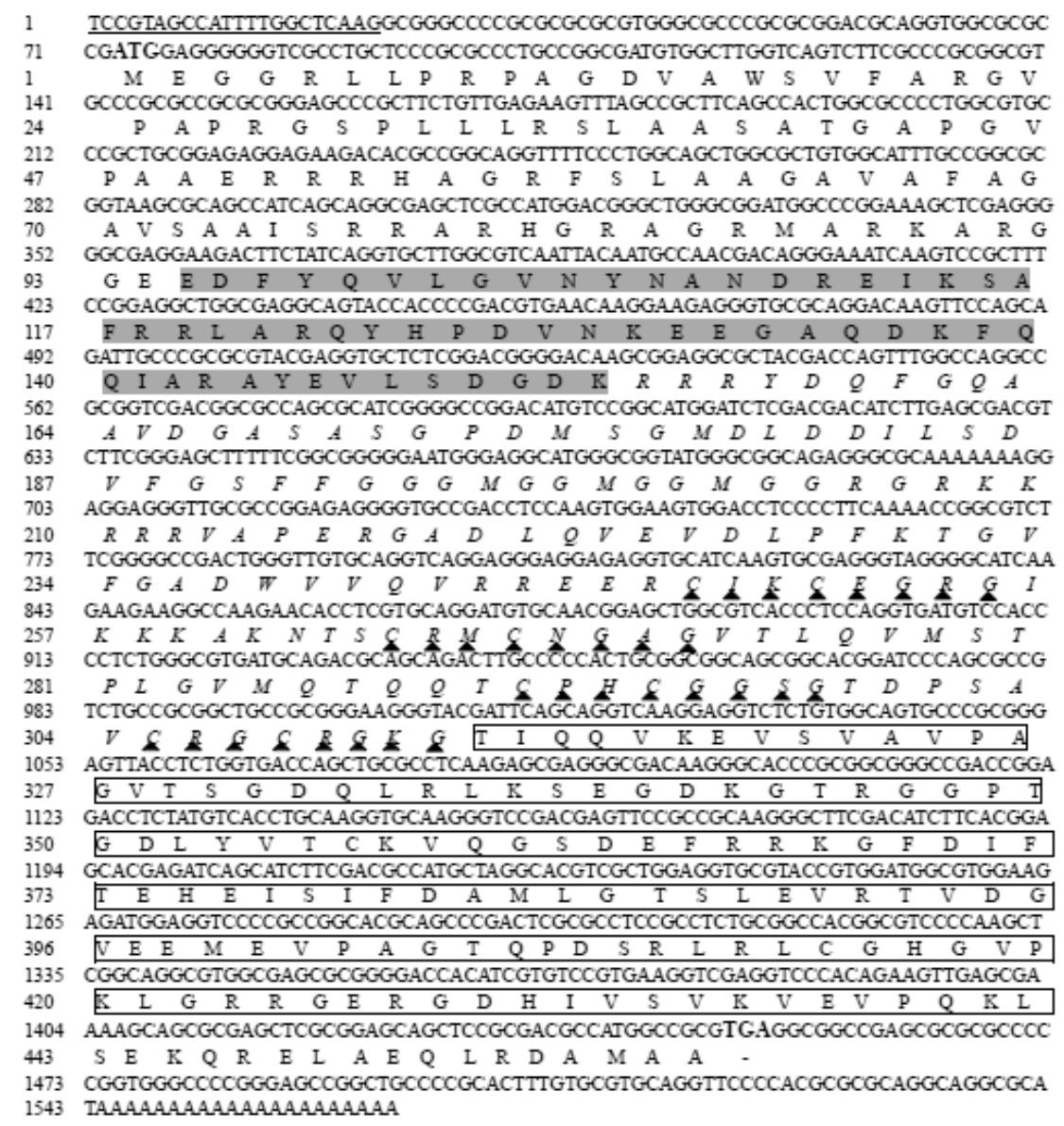

Figure 2. The cDNA and deduced amino acid sequences of StHsp40 (accession number: MN698835): boldface for start and stop codons; underline for DinoSL; dark gray background for the characteristic J-domain (95-153 aa); triangles for the typical 4 repeats of CxxCxGxG in the predicted zinc-finger domain (154-312 aa; italics); box for the putative C-terminal domain (313-442 aa).

\subsection{Transcriptional Responses of StHsp20 and StHsp40 to Temperature Stresses}

For StHsp20, after thermal treatments $\left(25\right.$ or $\left.30^{\circ} \mathrm{C}\right)$ for $1 \mathrm{~h}$, markedly elevated transcripts were detected as compared to that in $20{ }^{\circ} \mathrm{C}$ control (ANOVA, $p<0.01$; Figure 3A), while, however, no significant variation in transcripts was found in the treatments of lower temperatures $\left(15,10\right.$, or $\left.5^{\circ} \mathrm{C}\right)$ (ANOVA, $p>0.05$; Figure 3A). For StHsp40, significant augments were detected in StHsp40 transcripts after being subjected to both lower $\left(5,10\right.$, or $\left.15^{\circ} \mathrm{C}\right)$ and higher $\left(30^{\circ} \mathrm{C}\right)$ temperature stresses (ANOVA, $p<0.01$; Figure 3B). The lowest transcription was observed at $20-25^{\circ} \mathrm{C}$, and the transcriptions elevated with the magnitude of temperature changes along both the decreasing and increasing directions (Figure 3B).

For the mRNA accumulations over time in the exposure to a change of $\pm 10^{\circ} \mathrm{C}$, the mRNA expressions of both StHsp20 and StHsp20 in response to a $10{ }^{\circ} \mathrm{C}$ increase displayed a clearly time-dependent response with a similar trend during the $180 \mathrm{~min}$ exposure: the StHsp20 expression was significantly upregulated from $20 \mathrm{~min}$ and on and reached the highest at $120 \mathrm{~min}(\sim 14$-fold), and then declined (ANOVA, $p<0.01$; Figure 4A); the StHsp40 expression elevated significantly from 15 to $180 \mathrm{~min}$ (peak), with the peak being $\sim 9$-fold higher than that measured at the beginning of experiment 
(ANOVA, $p<0.01$; Figure 4C). In responses to a decrease of $10^{\circ} \mathrm{C}$, the StHsp20 mRNA accumulation was statistically similar to that in the $20^{\circ} \mathrm{C}$ control throughout the entire $180 \mathrm{~min}$ exposure (ANOVA, $p>0.05$; Figure 4B), while the StHsp40 expression was significantly upregulated from 10 min exposure and so on, with the peak observed at $120 \mathrm{~min}$, which then decreased (ANOVA, $p<0.01$; Figure 4D).

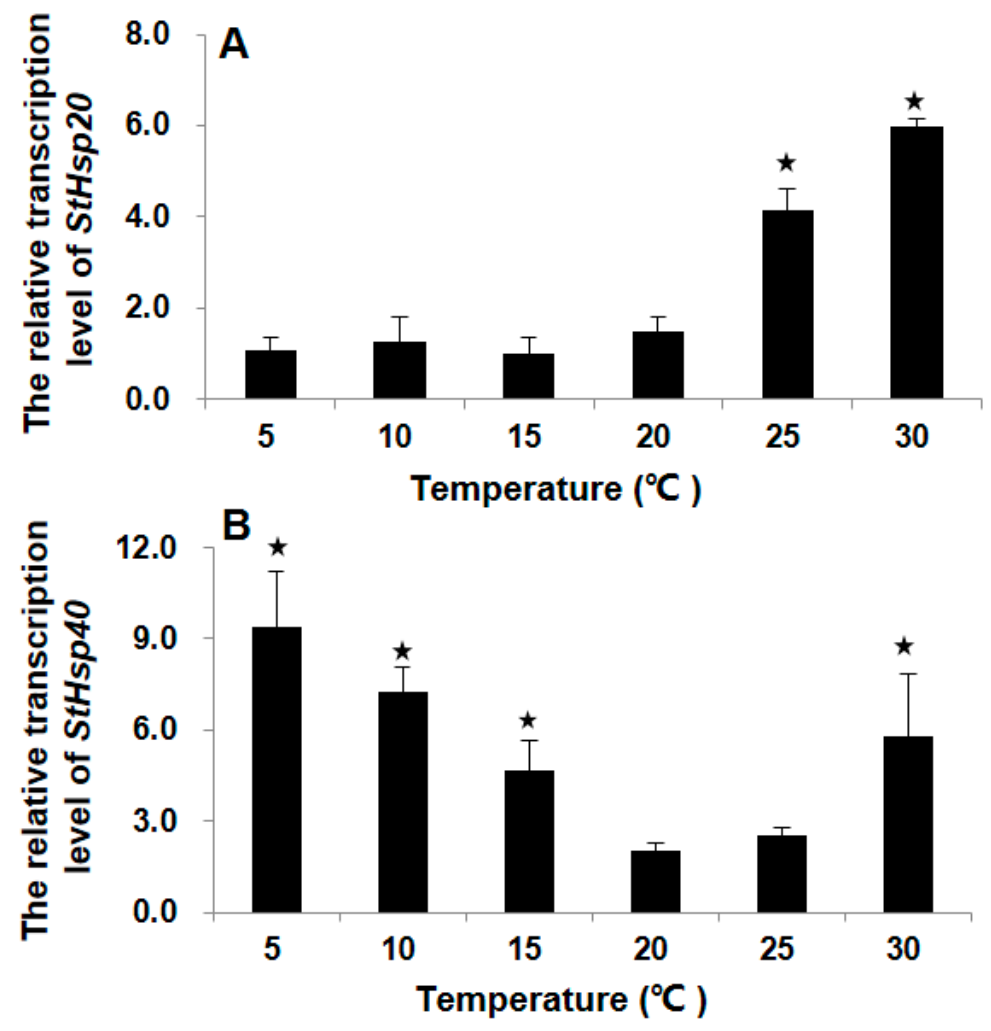

Figure 3. Transcription profiles of StHsp20 (A) and StHsp40 (B) in cells with different temperature treatments. The treatment groups that are significantly different $(p<0.05)$ relative to the control $\left(20^{\circ} \mathrm{C}\right.$ group) are noted with asterisks. Error bars represent the standard deviation from 3 replicates.
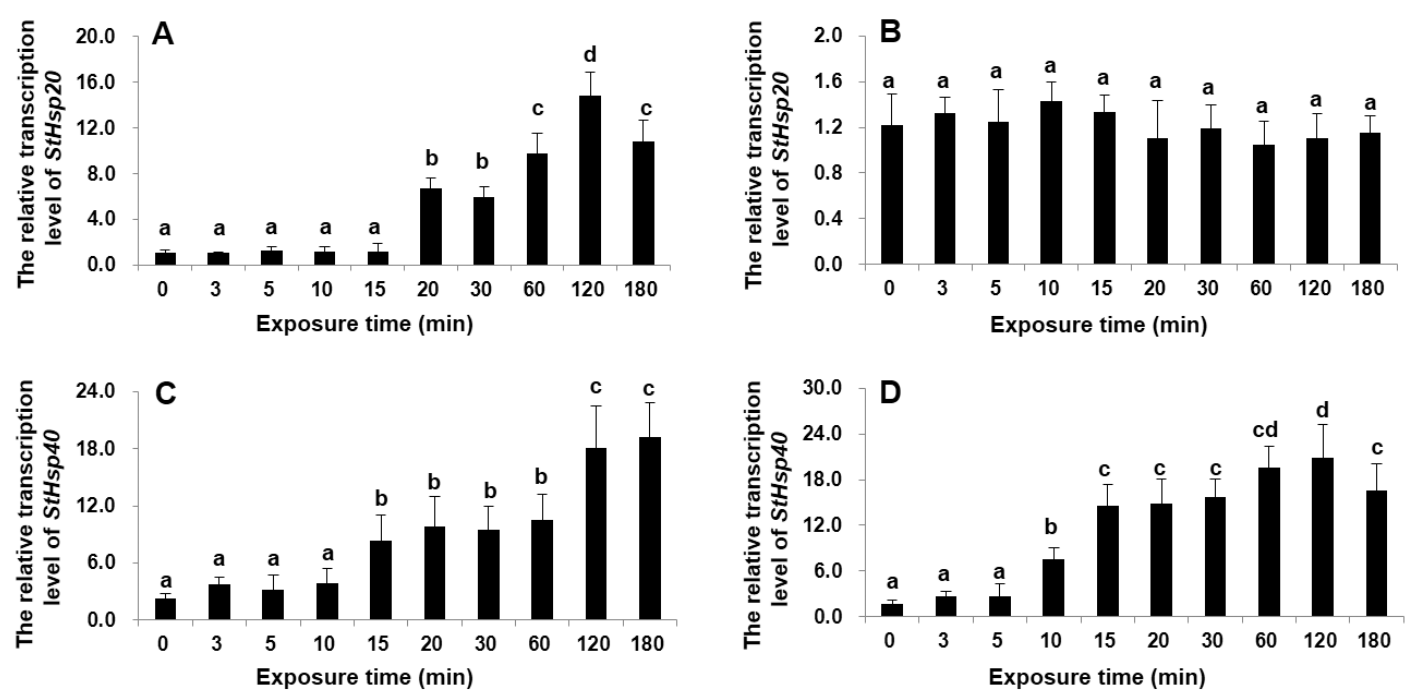

Figure 4. Transcription profiles of $\operatorname{StHsp} 20(\mathbf{A}, \mathbf{B})$ and $\operatorname{StHsp} 40(\mathbf{C}, \mathbf{D})$ in cells exposed to $30^{\circ} \mathrm{C}(\mathbf{A}, \mathbf{C})$ and $10{ }^{\circ} \mathrm{C}(\mathbf{B}, \mathbf{D})$ with durations from 3 to $180 \mathrm{~min}$. Different letters show significant differences $(p<0.05)$. Error bars represent the standard deviation from 3 replicates. 
In the experiment designed to compare the transcriptional responses between a moderate temperature stress (a $5{ }^{\circ} \mathrm{C}$ increase or decrease for each step) and a drastic temperature shock (a $10{ }^{\circ} \mathrm{C}$ increase or decrease in one step), the transcript levels of the two genes were not significantly stimulated by the moderate stress $\left( \pm 5^{\circ} \mathrm{C}\right.$ ) within the first $10 \mathrm{~min}$ (ANOVA, $p>0.05$; Figure 5 ). Both the moderate and drastic stresses for $1 \mathrm{~h}$ greatly stimulated the mRNA accumulation of StHsp 20 by more than four-fold (ANOVA, $p<0.01$; Figure 5A), with the transcription levels in the two groups statistically being the same (ANOVA, $p>0.05$; Figure $5 \mathrm{~A}$ ). Neither stepwise nor one-step decreasing temperature shocks could markedly affect its transcription (ANOVA, $p>0.05$; Figure 5B). For StHsp40, the transcriptional levels were significantly elevated in response to the drastic $10{ }^{\circ} \mathrm{C}$ shock, compared to the stepwise stresses (ANOVA, $p<0.01$; Figure 5C,D).
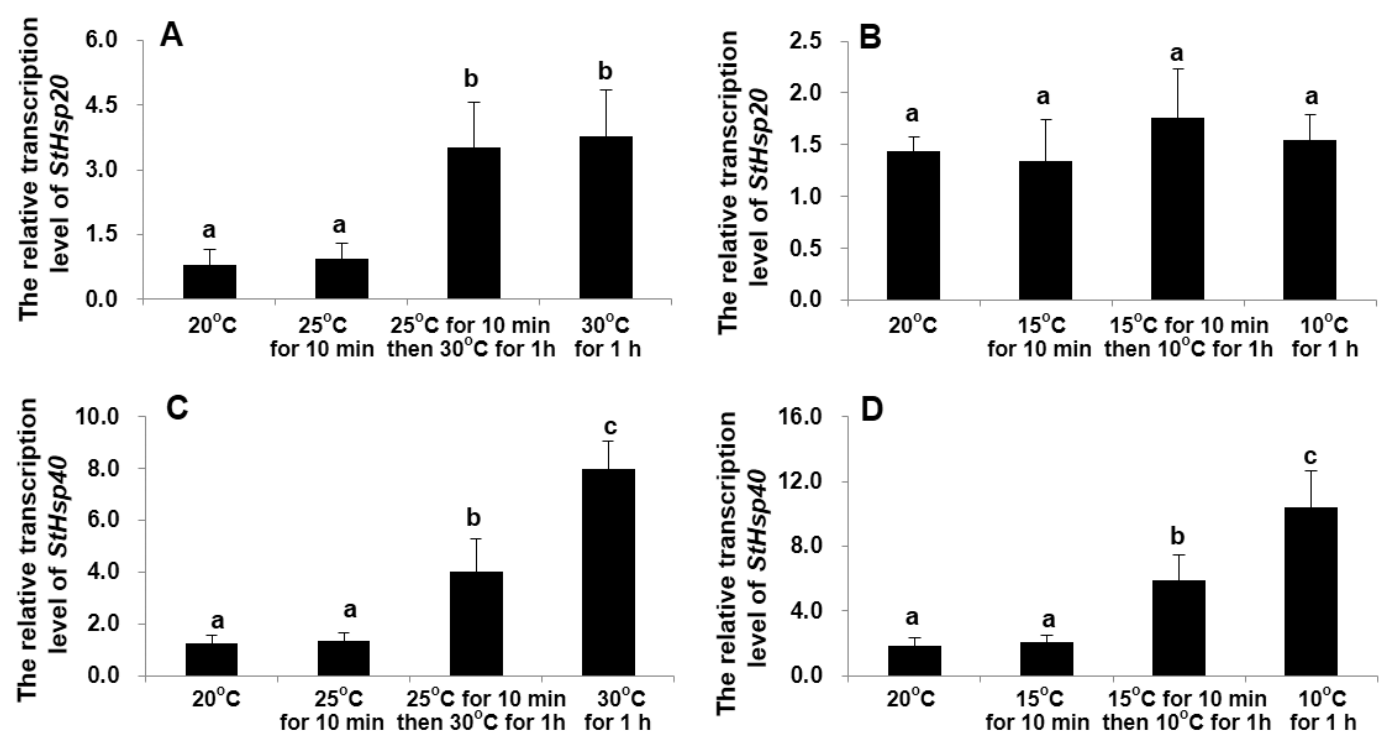

Figure 5. Transcription profiles of $\operatorname{StHsp} 20(\mathbf{A}, \mathbf{B})$ and $\operatorname{StHsp} 40(\mathbf{C}, \mathbf{D})$ in cultures exposed to one-step or stepwise temperature stress $\left(+10^{\circ} \mathrm{C}(\mathbf{A}, \mathbf{C}) ;-10^{\circ} \mathrm{C}(\mathbf{B}, \mathbf{D})\right.$. Different letters show significant differences $(p<0.05)$. Error bars represent the standard deviation from 3 replicates.

\subsection{Transcriptional Responses of StHsp20 and StHsp40 at Different Stages of Growth and Life Cycle}

Our results clearly demonstrated different responses of the two genes in responding to the alteration of life cycle stages of $S$. trochoidea. The expression of StHsp20 was observed to be statistically the same among all groups of the vegetative cells and resting cysts (ANOVA, $p>0.05$; Figure 6A). On the striking contrast, the mRNA abundance of StHsp40 in newly formed resting cysts was observed to be significantly higher than those in all other groups (ANOVA, $p<0.01$; Figure $6 \mathrm{~B}$ ), and no significant difference in mRNA abundance was observed among all other groups (ANOVA, $p>0.05$; Figure $6 \mathrm{~B}$ ). 


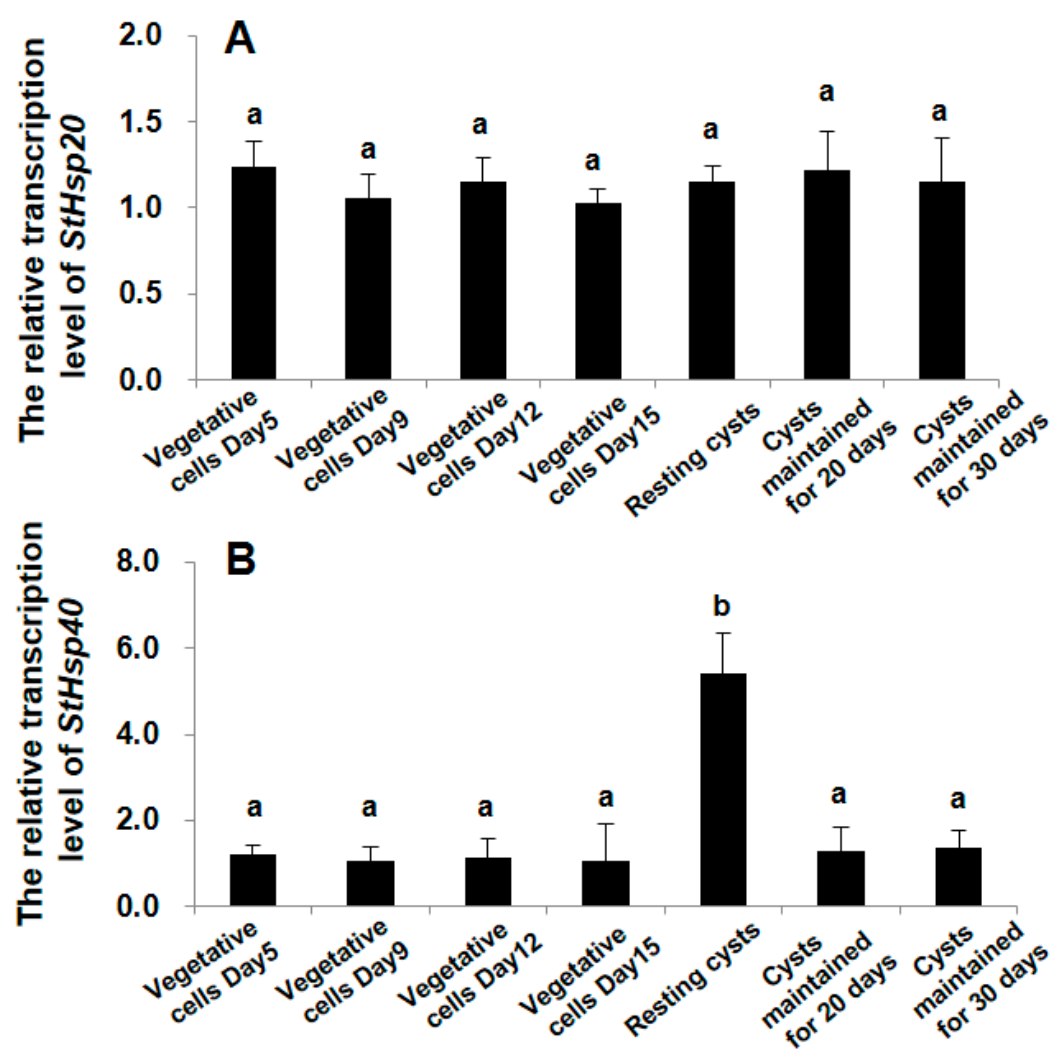

Figure 6. Transcription profiles of StHsp20 (A) and StHsp40 (B) in cells or resting cysts at different stage of life cycle. Different letters show significant differences $(p<0.05)$. Error bars represent the standard deviation from 3 replicates.

\section{Discussion}

\subsection{Structural Characterization of StHsp20 and StHsp40}

For the StHsp20 obtained from S. trochoidea in this study, the characteristic ACD is in accordance with the structural characteristics of other sHsp members $[19,21,22,76]$. The sHsp family probably contain the most diverse members in structure and function among various families of stress-responsive proteins [22]. Although their amino acid sequences are not as well conserved as those of the high molecular mass Hsps, plant sHSP monomers are all encoded by nuclear genes and share a conserved ACD located in the C- terminal $[19,20]$. Their $\mathrm{N}$-terminals are highly variable, which is important both in chaperone activity and substrate specificity [76]. The founding members that were given the name Hsp40s contain three characteristic domains: the J-domain, which is the typical domain for the Hsp40 family and responsible for the interaction with Hsp70; the zinc-finger domain, which is different from

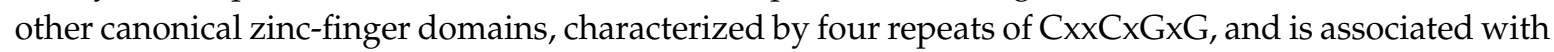
protein-protein interactions; the C-terminal domain, which facilitates dimerization and also participates in interactions with the substrates $[39,41]$. According to the presence or absence of these three domains, Hsp40 proteins have been classified into three groups: DNAJA group (retain all three domains like the original DnaJ protein of E. coli), DNAJB group (lack the zinc-finger domain), and DNAJC group (cover the J-domain only) $[38,41,43]$. The StHsp40 obtained from the dinoflagellate $S$. trochoidea in the present work contains all three structural domains as initially described in E. coli DnaJ, indicating our StHsp40 belongs to the DNAJA group. The conserved domains found in StHsp20 and StHsp40 imply that the functions of Hsp20 and Hsp40 may possibly be conserved among organisms of different taxa, and/or StHsp20 and StHsp40 function in the S. trochodea (and other dinoflagellates) the same way as identified from organisms of other evolutionarily distant groups. 


\subsection{Transcriptions of StHsp20 and StHsp40 in S. trochoidea Cells in Responding to Temperature Shocks}

The Hsps have been known to facilitate environment adaptation of organisms to various unfavorable scenarios potentially causing cellular damage by preventing cells from formation and accumulation of abnormal proteins within cells [18,77]. Temperature fluctuation or shock is a typical stimulus for Hsps production [78]. In the present study, the StHsp20 from S. trochoidea exhibited transcription profiles that were completely different between thermal ("heating") and cold ("cooling") stresses: the shocks of higher temperatures markedly increased the transcripts of StHsp2O but lower temperatures $\left(5-15^{\circ} \mathrm{C}\right)$ did not, suggesting StHsp20 may indeed function as a "heat shock protein" in the subsequent cellular defense to heat stress, as implied in the gene name. This is consistent with the observations in previous investigations on Arabidopsis [20], diatom [79], oyster [80], copepod [81], rotifer [82], and insect [83]. In the time-course tests (i.e., exposure to 30 or $10{ }^{\circ} \mathrm{C}$ for $0-180 \mathrm{~min}$ ), the $10{ }^{\circ} \mathrm{C}$ increment shock elicited drastically higher mRNA levels of StHsp20 after 20 min exposure and maintained levels higher than those in the initial period from 0 to $15 \mathrm{~min}$. Our recent work also observed rapid and significant increases in the mRNA amounts of Hsp60 and Hsp10 in S. trochoidea within 5 and $10 \mathrm{~min}$, respectively, after exposing cells to temperature shocks from 20 to $30^{\circ} \mathrm{C}$ and from 20 to $10^{\circ} \mathrm{C}$ [58], implying that $H s p 20, H s p 60$, and Hsp10 are all involved in thermal adaptation of the species but a more urgent or sensitive response in Hsp60 and Hsp10. These results together also imply that the temperature adaptation of dinoflagellates is accurately controlled by an orchestrated transcription of different Hsps. Lower-temperature stress (a decrease from 20 to 15,10 or $5^{\circ} \mathrm{C}$ ), regardless of a moderate or drastic stress, however, did not significantly stimulate the transcription of StHsp20, which is different from the responses of Hsp60 and Hsp10 [58], indicating StHsp2O not a gene involved in cold shock adaptation. These results may also imply that the thermal and cold adaptation/acclimation in dinoflagellates are controlled by mechanisms and components that are associated by different. The StHsp2O was probably related to the heat tolerance of the species.

The transcript levels of StHsp 40 were greatly stimulated by both thermal and cold inducement within a time period of at least $3 \mathrm{~h}$, regardless of moderate change or drastic shocks. This result suggested that the $S t H s p 40$ probably plays roles in stabilizing and protecting proteins during both heat and cold stresses in S. trochoidea, akin to previously confirmed temperature responses of $H s p 40$ s in other organisms by multiple investigations [42,44,45]. We detected significantly elevated StHsp 40 transcriptions in cells exposing higher $\left(+10^{\circ} \mathrm{C}\right)$ and lower $\left(-10^{\circ} \mathrm{C}\right)$ temperatures after 15 and $10 \mathrm{~min}$, respectively. Comparing results between the moderate $\left(5^{\circ} \mathrm{C}\right.$ change for each step) and drastic $\left(10^{\circ} \mathrm{C}\right.$ change for one step) temperature stress, StHsp40 transcripts were observed to be significantly higher in the latter groups. Our previous work on Hsp70 in another HAB-forming dinoflagellate Akashiwo sanguinea found that the same drastic temperature shocks significantly stimulated its transcription within 10 min, and it was also higher than that observed in the moderate changes in temperature [63]. These results demonstrated that $H s p 40$ and $H s p 70$ in dinoflagellates have similar transcriptional responses to temperature stresses. It was previously inferred that $H s p 40$ may functionally interact with $H s p 70$ in the same heat shock pathway in dinoflagellates, where Hsp40 primarily acts as coupling factors to stimulate ATP hydrolysis of their chaperone proteins, Hsp70s [39,40,43]. Our results together support this inference and suggest $S t H s p 40$ is closely involved in the adaptation to both higher and lower temperature fluctuations of $S$. trochoidea.

\subsection{Differential Transcriptional Responses of StHsp20 and StHsp40 to the Alteration of Life Cycle Stages (Vegetative Cells vs. Resting Cysts)}

Although Hsp proteins were initially known for heat shock response, evidence available in the literatures has indicated that various stressors other than temperature could stimulate their transcriptions, including, indeed, almost all known stresses [77,78]. For dinoflagellates, together with some other free-living protists, the formation of cysts is an adaptive strategy to survive in stressful conditions $[5,57,84]$. This study, however, did not observe significant transcriptions of StHsp2O changing with alterations of growth stages of vegetative cells and that of life cycle stages (from 
vegetative cells to resting cysts), suggesting the new generated StHsp20 might not function during resting stage formation and persistence of the species. Many higher plants have more than $20 \mathrm{sHsps}$, forming a more diverse family than other Hsps with respect to sequence similarity, cellular location, and functions [18]. The presence of abundant and heterogenous sHSPs suggests that they may have different or various physiological functions [23]. Therefore, further characterization of more sHsps from more dinoflagellate species at different life cycle stages is highly desirable for a more insightful understanding about their biological and ecological functions in dinoflagellates.

Apart from functioning in protecting cells from deleterious stresses, Hsps are proven to constitutively express at normal growth temperatures and play essential and indispensable roles in the life cycle $[77,78]$. Their transcriptions can be evoked even by non-environmental cues such as genetic stress $[18,77,85]$. Resting cyst of dinoflagellate is a benthic, dormant stage usually resulting from sexual reproduction. Sexual reproduction, which may increase genetic variance affect the ecology and evolution of species, is thus a kind of potential genetic stress [77,85]. In the present study, drastically elevated StHsp40 transcription was detected in newly formed resting cysts, compared to those in vegetative cells and those in resting cysts maintained in the cold for a longer time, which might be viewed as a response to intrinsic stress resulting from sexual reproduction and encystment. It is also suggested that $\mathrm{StHsp} 40$ might have functions in the resting cyst formation of $S$. trochoidea. This transcription pattern is also consistent with observations in mouse, yeast, fruit fly, Haliotis asinine, and mammalian cells, in the sense that Hsps transcriptions were activated upon exposure to genetic stresses such as inbreeding [85,86], senescence [87], deleterious mutations [88,89], and morphogenesis [77,90,91].

In nature, many species are exposed to hostile environmental conditions, such as high temperatures and high levels of toxicity. It is a common phenomenon that individuals at certain life stage are prone to being more vulnerable to stressful environments, a typical example is animals at the juvenile stage wherein mobility is often low and behavioral avoidance is limited. Studies on several organisms have found that occupation of different environments for different life stages might select for life-stage-specific Hsp expression and resistance [77]. Works on seeds of higher plants revealed that Hsp members, such Hsp70 and sHsp, were upregulated at transcriptional level by dormant stage-inducing conditions in the absence of abiotic stress [92]. Their protein abundance was also recorded to be higher in dormant stage compared to that in non-dormant stage and significantly decreased during germination [93]. The prominent expression of these genes and proteins were proposed to be part of the seed developmental program, which are required to ensure the proper folding of other proteins at the dormant state [92,93]. A paralleled finding was observed in the dinoflagellate Akashiwo sanguinea, of which the Hsp70 transcription peaked in newly formed resting cysts undergoing morphogenesis and then dropped to lower levels in more mature (i.e., long-stored) cysts [63]. Our recent work on S. trochoidea also detected significantly higher transcriptions of Hsp60 and Hsp 10 in resting cysts (both newly formed and long-stored cysts) relative to that in vegetative cells [58]. All of these results seem to imply some relationship between Hsps and life history traits of dinoflagellates; however, detailed knowledge is still in its infancy. It can be the starting point for future research to understand the physiological relevance of Hsps in this unique group of eukaryotes. Several gene expression studies have shown that dinoflagellates may rely heavily on posttranscriptional mechanisms [94,95]. Therefore, future works on more Hsp members in dinoflagellates under various stresses and developmental procession from both the transcriptional and translational levels may help us to enrich the knowledge about their ecological implications in relation not only to environmental cues in general but also to genetic stress of intrinsic nature in this unique lineage of eukaryotes.

\section{Conclusions}

In summary, we used the cosmopolitan, toxic, and resting-cyst-producing dinoflagellate, Scrippsiella trochoidea, as a representative species of HAB-forming dinoflagellates to probe the potential roles of $H s p 20$ and $H s p 40$ genes in dinoflagellates during adaptation to temperature fluctuation and alteration of different life stages. We found that $S t H s p 20$ and $S t H s p 40$ exhibited highly similar mRNA 
accumulation patterns when exposed to heat stresses but completely different toward cold stresses, implying the mechanisms underlying thermal and cold acclimation in dinoflagellates are regulated by different sets of genes. The StHsp20 was probably related to the heat tolerance of the species and StHsp 40 was closely involved in the adaptation to both higher and lower temperature fluctuations. Furthermore, we found StHsp40 displayed a significantly higher transcriptional level in newly formed resting cysts, which might be a response to intrinsic stress stemmed from encystment and also implied StHsp40 might be directly involved in resting cyst formation of $S$. trochoidea. Although the data we acquired here are still a long way from being speculatedthe possible application into prevention, control, and mitigation of HABs, our findings provide clues to understand the molecular underpinnings underlying the two well-documented adaptive strategies of HABs-forming dinoflagellates, which might provide theoretical support for improving HABs management strategies and response in the future.

Supplementary Materials: The following are available online at http://www.mdpi.com/2079-7737/9/11/408/s1, Figure S1: Morphological observations for (A) vegetative cell and (B) resting cyst of Scrippsiella trochoidea under light microscope, Figure S2: Growth curve of vegetative cells of Scrippsiella trochoidea.

Author Contributions: Conceptualization, Y.D. and Y.Z.T.; methodology, Y.D. and Z.H.; software, Z.H. and L.S.; validation, Y.D., Z.H., L.S., Z.C., and Y.Z.T.; formal analysis, Z.C.; investigation, Y.D.; resources, Y.D. and Z.C.; data curation, Z.H.; writing-original draft preparation, Y.D. and Z.H.; writing-review and editing, L.S. and Y.Z.; visualization, Y.Z.T.; supervision, Y.T.; project administration, Y.Z.T.; funding acquisition, Y.Z.T. All authors have read and agreed to the published version of the manuscript.

Funding: This research was funded by the Key Deployment Project of Centre for Ocean Mega-Research of Science, Chinese Academy of Sciences (Grant No. COMS2019Q09) and the National Science Foundation of China (Grant Numbers 41606126, 61533011, and 41776125).

Conflicts of Interest: All the authors declare that they have no conflict of interest.

\section{References}

1. Hackett, J.D.; Anderson, D.M.; Erdner, D.L.; Bhattacharya, D. Dinoflagellates: A remarkable evolutionary experiment. Am. J. Bot. 2004, 91, 1523-1534. [CrossRef] [PubMed]

2. Bi, Y.; Wang, F.; Zhang, W. Omics analysis for dinoflagellates biology research. Microorganisms 2019, 7, 288. [CrossRef] [PubMed]

3. Smayda, T.J. Harmful algal blooms: Their ecophysiology and general relevance to blooms in phytoplankton the sea. Limnol. Oceanogr. 1997, 42, 1137-1153. [CrossRef]

4. Murray, S.A.; Suggett, D.J.; Doblin, M.A.; Kohli, G.S.; Seymour, J.R.; Fabris, M.; Ralph, P.J. Unravelling the functional genetics of dinoflagellates: A review of approaches and opportunities. Perspect. Phycol. 2016, 3, 37-52. [CrossRef]

5. Tang, Y.Z.; Hu, Z.X.; Deng, Y.Y. Characteristical life history (resting cyst) provides a mechanism for recurrence and geographic expansion of harmful algal blooms of dinoflagellates: A review. Stud. Mar. Sin. 2016, 51, 132-154.

6. Hallegraeff, G.M.; Bolch, C.J. Transport of diatom and dinoflagellate resting spores in ships' ballast water: Implications for plankton biogeography and aquaculture. J. Plankton. Res. 1992, 14, 1067-1084. [CrossRef]

7. Nehring, S. Mechanisms for recurrent nuisance algal blooms in coastal zones: Resting cyst formation as life-strategy of dinoflagellates. In Interdisciplinary Discussion of Coastal Research and Coastal Management Issues and Problems; Lang: Frankfurt, Germany, 1993.

8. Smayda, T.J. Reflections on the ballast water dispersal-harmful algal bloom paradigm. Harmful Algae 2007, 6, 601-622. [CrossRef]

9. Bravo, I.; Figueroa, R.I. Towards an ecological understanding of dinoflagellate cyst functions. Microorganisms 2014, 2, 11-32. [CrossRef]

10. Liu, Y.Y.; Hu, Z.X.; Deng, Y.Y.; Tang, Y.Z. Evidence for production of sexual resting cysts by the toxic dinoflagellate Karenia mikimotoi in clonal cultures and marine sediments. J. Phycol. 2020, 56, 121-134. [CrossRef]

11. Rengefors, K.; Karlsson, I.; Hansson, L.A. Algal cyst dormancy: A temporal escape from herbivory. Proc. R. Soc. Lond. B 1998, 265, 1353-1358. [CrossRef]

12. Elbrăchter, M. Dinoflagellate reproduction: Progress and conflicts. J. Phycol. 2003, 39, 629-632. [CrossRef] 
13. Xu, N.; Lv, S.H.; Chen, J.F.; He, L.S.; Xie, L.C.; Qi, Y.Z. The influence of water temperature and salinity on the growth of Scrippsiella trochoidea. Mar. Environ. Sci. 2004, 23, 36-38.

14. Deng, G.; Li, Y.G.; Hu, H.J.; Qi, Y.Z.; Geng, Y.H.; Li, Z.K. Effects of temperature, light and pH on photosynthesis, and of light-dark cycle on growth rate and biomass of Scrippsiella trochoidea and Alexandrium tamarense. J. Wuhan Bot. Res. 2004, 22, 129-135.

15. Kim, D.I.; Matsuyama, Y.; Nagasoe, S.; Yamaguchi, M.; Yoon, Y.; Oshima, Y.; Imada, N.; Honjo, T. Effects of temperature, salinity and irradiance on the growth of the harmful red tide dinoflagellate Cochlodinium polykrikoides Margalef (Dinophyceae). J. Plankton. Res. 2004, 26, 61-66. [CrossRef]

16. Matsubara, T.; Nagasoe, S.; Yamasaki, Y.; Shikata, T.; Shimasaki, Y.; Oshima, Y.; Honjo, T. Effects of temperature, salinity, and irradiance on the growth of the dinoflagellate Akashiwo sanguinea. J. Exp. Mar. Biol. Ecol. 2007, 342, 226-230. [CrossRef]

17. Zhou, M.J.; Yu, R.C. Mechanisms and impacts of harmful algal blooms and the count measures. Chin. J. Nat. 2007, 29, 72-77.

18. Wang, W.; Vinocur, B.; Shoseyov, O.; Altman, A. Role of plant heat-shock proteins and molecular chaperones in the abiotic stress response. Trends Plant Sci. 2004, 9, 244-252. [CrossRef] [PubMed]

19. Mahmood, T.; Safdar, W.; Abbasi, B.H.; Naqvi, S.M.S. An overview on the small heat shock proteins. Afr. J. Biotechnol. 2010, 9, 927-949.

20. Waters, E.R. The evolution, function, structure, and expression of the plant sHSPs. J. Exp. Bot. 2013, 64, 391-403. [CrossRef]

21. Sun, Y.; MacRae, T.H. Small heat shock proteins: Molecular structure and chaperone function. Cell Mol. Life Sci. 2005, 62, 2460-2476. [CrossRef]

22. Franck, E.; Madsen, O.; Rheede, T.V.; Ricard, G.; Huynen, M.A.; de Jong, W.W. Evolutionary diversity of vertebrate small heat shock proteins. J. Mol. Evol. 2004, 59, 792-805. [CrossRef] [PubMed]

23. Vierling, R.; Nguyen, H.T. Heat-shock gene expression in diploid wheat genotypes differing in thermal tolerance. Crop Sci. 1992, 32, 370-377. [CrossRef]

24. Kim, K.K.; Kim, R.; Kim, S.H. Crystal structure of a small heat shock protein. Nature 1998, 394, 595-599. [CrossRef] [PubMed]

25. Haslbeck, M.; Kastenmuller, A.; Buchner, J.; Weinkauf, S.; Braun, N. Structural dynamics of archaeal small heat shock proteins. J. Mol. Biol. 2008, 378, 362-374. [CrossRef] [PubMed]

26. Linder, B.; Jin, Z.; Freedmans, J.H.; Rubin, C.S. Molecular characterization of a novel, developmentally regulated small embryonic chaperone from Caenorhabditis elegans. J. Biol. Chem. 1996, 271, 30158-30166. [CrossRef]

27. Shirk, P.D.; Broza, R.; Hemphill, M.; Perera, O.P. $\alpha$-Crystallin protein cognates in eggs of the moth, Plodia interpunctella: Possible chaperones for the follicular epithelium yolk protein. Insect Biochem. Mol. Biol. 1998, 28, 151-161. [CrossRef]

28. Reineke, A. Identification and expression of a small heat shock protein in two lines of the endoparasitic wasp Venturia canescens. Comp. Biochem. Physiol. Part A 2005, 141, 60-69. [CrossRef]

29. Huang, L.H.; Wang, C.Z.; Kang, L. Cloning and expression of five heat shock protein genes in relation to cold hardening and development in the leafminer, Liriomyza sativa. J. Insect Physiol. 2009, 55, 279-285. [CrossRef]

30. Wieske, M.; Benndorf, R.; Behlke, J.; Dolling, R.; Grelle, G.; Bielka, H.; Lutsch, G. Defined sequence segments of the small heat shock proteins HSP25 and $\alpha$ B-crystallin inhibit actin polymerization. Eur. J. Biochem. 2001, 268, 2083-2090. [CrossRef]

31. Quinlan, R. Cytoskeletal competence requires protein chaperones. Prog. Mol. Sub. Cell Biol. 2002, 28, $219-234$.

32. Wood, K.L.; Voss, O.H.; Huang, Q.; Parihar, A.; Mehta, N.; Batra, S.; Doseff, A.I. The small heat shock protein 27 is a key regulator of CD8+ CD57+ lymphocyte survival. J. Immunol. 2010, 184, 5582-5588. [CrossRef] [PubMed]

33. Tsvetkova, N.M.; Horváth, I.; Török, Z.; Wolkers, W.F.; Balogi, Z.; Shigapova, N.; Crowe, L.M.; Tablin, F.; Vierling, E.; Crowe, J.H.; et al. Small heat-shock proteins regulate membrane lipid polymorphism. Proc. Natl. Acad. Sci. USA 2002, 99, 13504-13509. [CrossRef] [PubMed]

34. Mackay, D.S.; Andley, U.P.; Shiels, A. Cell death triggered by a novel mutation in the alphaA-crystallin gene underlies autosomal dominant cataract linked to chromosome 21q. Eur. J. Hum. Genet. 2003, 11, 784-793. [CrossRef] [PubMed] 
35. Evgrafov, O.V.; Mersiyanova, I.; Irobi, J.; Van Den Bosch, L.; Dierick, I.; Leung, C.L.; Schagina, O.; Verpoorten, N.; Van Impe, K.; Fedotov, V.; et al. Mutant small heat-shock protein 27 causes axonal Charcot-Marie-Tooth disease and distal hereditary motor neuropathy. Nat. Genet. 2004, 36, 602-606. [CrossRef] [PubMed]

36. Selcen, D.; Engel, A.G. Myofibrillar myopathy caused by novel dominant negative a B-crystallin mutations. Ann. Neurol. 2003, 54, 804-810. [CrossRef] [PubMed]

37. Yochem, J.; Uchida, H.; Sunshine, M.; Saito, H.; Georgopoulos, C.P.; Feiss, M. Genetic analysis of two genes, dnaJ and dnaK, necessary for Escherichia coli and bacteriophage lambda DNA replication. Mol. Gen. Genet. 1978, 164, 9-14. [CrossRef]

38. Liberek, K.; Georgopoulos, C.; Zylicz, M. Role of the Escherichia coli DnaK and DnaJ heat shock proteins in the initiation of bacteriophage lambda DNA replication. Proc. Natl. Acad. Sci. USA 1988, 85, 6632-6636. [CrossRef]

39. Qiu, X.B.; Shao, Y.M.; Miao, S.; Wang, L. The diversity of the DnaJ/Hsp40 family, the crucial partners for Hsp70 chaperones. Cell. Mol. Life Sci. 2006, 63, 2560-2570. [CrossRef]

40. Kampinga, H.H.; Craig, E.A. The Hsp70 chaperone machinery: J proteins as drivers of functional specificity. Nat. Rev. Mol. Cell Biol. 2010, 11, 579-592. [CrossRef]

41. Pulido, P.; Leister, D. Novel DNA-related proteins in Arabidopsis thaliana. New Phytol. 2018, 217, 480-490. [CrossRef]

42. Wang, G.; Zhou, S.; Luo, Y.; Ma, C.; Gong, Y.; Zhou, Y.; Gao, S.; Huang, Z.; Yan, L.; Hu, Y.; et al. The heat shock protein 40 LeDnaJ regulates stress resistance and indole-3-acetic acid biosynthesis in Lentinula edodes. Fungal Genet. Biol. 2018, 118, 37-44. [CrossRef] [PubMed]

43. Walsh, P.; Bursać, D.; Law, Y.C.; Cyr, D.; Lithgow, T. The J-protein family: Modulating protein assembly, disassembly and translocation. EMBO Rep. 2004, 5, 567-571. [CrossRef] [PubMed]

44. Rajan, V.B.; D'Silva, P. Arabidopsis thaliana J-class heat shock proteins: Cellular stress sensors. Funct. Integr. Genom. 2009, 9, 433-446. [CrossRef] [PubMed]

45. Liu, Z.; Xin, M.; Qin, J.; Peng, H.; Ni, Z.; Yao, Y.; Sun, Q. Temporal transcriptome profiling reveals expression partitioning of homeologous genes contributing to heat and drought acclimation in wheat (Triticum aestivum L.). BMC Plant Biol. 2015, 15, 1-20. [CrossRef]

46. Caplan, A.J.; Tsai, J.; Casey, P.J.; Douglas, M.G. Farnesylation of YDJ1p is required for function at elevated growth temperatures in Saccharomyces cerevisiae. J. Biol. Chem. 1992, 267, 18890-18895.

47. Suetsugu, N.; Kagawa, T.; Wada, M. An auxilin-like J-domain protein, JAC1, regulates phototropin-mediated chloroplast movement in Arabidopsis. Plant Physiol. 2005, 139, 151-162. [CrossRef]

48. Shen, L.; Yu, H. The J-domain protein J3 mediates the integration of flowering signals in Arabidopsis. Plant Cell 2001, 23, 499-514. [CrossRef]

49. Levin, R.A.; Beltran, V.H.; Hill, R.; Kjelleberg, S.; Mcdougald, D.; Steinberg, P.D.; Va Oppen, M.J. Sex, scavengers, and chaperones: Transcriptome secrets of divergent Symbiodinium thermal tolerances. Mol. Biol. Evol. 2016, 33, 2201-2215. [CrossRef]

50. Gierz, S.L.; Foret, S.; Leggat, W. Transcriptomic analysis of thermally stressed Symbiodinium reveals differential expression of stress and metabolism genes. Front Plant Sci. 2017, 8, 271. [CrossRef]

51. Lei, Q.; Lu, S. Molecular ecological responses of dinoflagellate, Karenia mikimotoi to environmental nitrate stress. Mar. Pollut. Bull. 2011, 62, 2692-2699. [CrossRef]

52. Zhang, C.; Chen, G.; Wang, Y.; Guo, C.; Zhou, J. Physiological and molecular responses of Prorocentrum donghaiense to dissolved inorganic phosphorus limitation. Mar. Pollut. Bull. 2018, 129, 562-572. [CrossRef] [PubMed]

53. Zhang, S.; Zhang, Y.; Xie, Z.; Zhang, H.; Lin, L.; Wang, D. iTRAQ-based quantitative proteomic analysis of a toxigenic dinoflagellate Alexandrium catenella and its non-toxic mutant. Proteomics 2015, 15, 4041-4050. [CrossRef] [PubMed]

54. Steidinger, K.A.; Tangen, K. Dinoflagellates. In Identifying Marine Diatoms and Dinoflagellates; Academic Press: New York, NY, USA, 1996.

55. Tang, Y.Z.; Gobler, C.J. Lethal effects of Northwest Atlantic Ocean isolates of the dinoflagellate, Scrippsiella trochoidea, on Eastern oyster (Crassostrea virginica) and Northern quahog (Mercenaria mercenaria) larvae. Mar. Biol. 2012, 159, 199-210. [CrossRef] 
56. Wang, Z.; Yu, Z.; Song, X.; Cao, X.; Zhang, Y. Effects of ammonium and nitrate on encystment and growth of Scrippsiella trochoidea. Chin. Sci. Bull. 2014, 59, 4491-4497. [CrossRef]

57. Deng, Y.Y.; Hu, Z.X.; Shang, L.X.; Peng, Q.C.; Tang, Y.Z. Transcriptomic analyses of Scrippsiella trochoidea reveals processes regulating encystment and dormancy in the life cycle of a dinoflagellate, with a particular attention to the role of abscisic acid. Front. Microbiol. 2017, 8, 2450. [CrossRef]

58. Deng, Y.Y.; Hu, Z.X.; Chai, Z.Y.; Tang, Y.Z. Molecular cloning of heat shock protein 60 (Hsp60) and 10 (Hsp10) genes from the cosmopolitan and harmful dinoflagellate Scrippsiella trochoidea and their differential transcriptions responding to temperature stress and alteration of life cycle. Mar. Biol. 2019, 166, 7. [CrossRef]

59. Deng, Y.Y.; Hu, Z.X.; Chai, Z.Y.; Tang, Y.Z. Cloning and comparative studies of proliferating cell nuclear antigen (PCNA) genes for nine dinoflagellates. J. Appl. Phycol. 2019, 31, 2969-2979. [CrossRef]

60. Deng, Y.Y.; Hu, Z.X.; Chai, Z.Y.; Tang, Y.Z. Cloning and partial characterization of a cold shock domain-containing protein gene from the dinoflagellate Scrippsiella trochoidea. J. Eukaryot. Microbiol. 2019, 66, 393-403. [CrossRef]

61. Guillard, R.R.L. Culture of phytoplankton for feeding marine invertebrates. In Culture of Marine Invertebrate Animals; Springer: Boston, MA, USA, 1975.

62. Doblin, M.A.; Blackburn, S.I.; Hallegraeff, G.M. Growth and biomass stimulation of the toxic dinoflagellate Gymnodinium catenatum (Graham) by dissolved organic substances. J. Exp. Mar. Biol. Ecol. 1999, 236, 33-47. [CrossRef]

63. Deng, Y.Y.; Hu, Z.X.; Zhan, Z.F.; Ma, Z.P.; Tang, Y.Z. Differential expressions of an Hsp70 gene in the dinoflagellate Akashiwo sanguinea in response to temperature stress and transition of life cycle and its implications. Harmful Alage 2015, 50, 57-64. [CrossRef]

64. Zhang, H.; Hou, Y.; Miranda, L.; Campbell, D.A.; Sturm, N.R.; Gaasterland, T.; Lin, S. Spliced leader RNA trans-splicing in dinoflagellates. Proc. Natl. Acad. Sci. USA 2007, 104, 4618-4623. [CrossRef] [PubMed]

65. Lin, S. Genomic understanding of dinoflagellates. Res. Microbiol. 2011, 162, 551-569. [CrossRef] [PubMed]

66. Rombel, I.T.; Sykes, K.F.; Rayner, S.; Johnston, S.A. ORF-Finder: A vector for high-throughput gene identification. Gene 2002, 282, 33-41. [CrossRef]

67. Altschul, S.F.; Madden, T.L.; Schaffer, A.A.; Zhang, J.H.; Zhang, Z.; Miller, W.; Lipman, D.J. Gapped BLAST and PSI-BLAST: A new generation of protein database search programs. Nucleic Acids Res. 1997, 25, 3389-3402. [CrossRef]

68. Gasteiger, E.; Hoogland, C.; Gattiker, A.; Duvaud, S.; Wilkins, M.R.; Appel, R.D.; Bairoch, A. The Proteomics Protocols Handbook; Humana Press: New Jersey, NJ, USA, 2005.

69. Geourjon, C.; Deleage, G. SOPMA: Significant improvements in protein secondary structure prediction by consensus prediction from multiple alignments. Comput. Appl. Biosci. 1995, 11, 681-684. [CrossRef]

70. Krogh, A.; Larsson, B.; Von Heijne, B.; Sonnhammer, E.L.L. Predicting transmembrane protein topology with a hidden Markov model: Application to complete genomes. J. Mol. Biol. 2001, 305, 567-580. [CrossRef]

71. Petersen, T.N.; Brunak, S.; Von Heijne, G.; Nielsen, H. SignalP 4.0: Discriminating signal peptides from transmembrane regions. Nat. Methods 2011, 8, 785-786. [CrossRef]

72. Pfaffl, M. A new mathematical model for relative quantification in real-time RT-PCR. Nucleic Acids Res. 2001, 29, 2002-2007. [CrossRef]

73. Radonic, A.; Thulke, S.; Mackay, I.; Landt, O.; Siegert, W.; Nitsche, A. Guideline to reference gene selection for quantitative real-time PCR. Biochem. Bioph. Res. Commun. 2004, 313, 856-862. [CrossRef]

74. Schmittgen, T.D.; Zakrajsek, B.A.; Mills, A.G.; Gorn, V.; Singer, M.J.; Reed, M.W. Quantitative reverse transcription-polymerase chain reaction to study mRNA decay: Comparison of endpoint and real-time methods. Anal. Biochem. 2000, 285, 194-204. [CrossRef]

75. Hellemans, J.; Mortier, G.; De Paepe, A.; Speleman, F.; Vandesompele, J. qBase relative quantification framework and software for management and automated analysis of real-time quantitative PCR data. Genome Biol. 2007, 8, R19. [CrossRef] [PubMed]

76. Basha, E.; Friedrich, K.L.; Vierling, E. The N-terminal arm of small heat shock proteins is important for both chaperone activity and substrate specificity. J. Biol. Chem. 2006, 281, 39943-39952. [CrossRef] [PubMed]

77. Sørensen, J.G.; Kristensen, T.N.; Loeschcke, V. The evolutionary and ecological role of heat shock proteins. Ecol. Lett. 2003, 6, 1025-1037. [CrossRef]

78. Feder, M.E.; Hofmann, G.E. Heat-shock proteins, molecular chaperones, and the stress response: Evolutionary and ecological physiology. Annu. Rev. Physiol. 1999, 61, 243-282. [CrossRef] [PubMed] 
79. Lee, M.; Guo, R.; Ki, J. Different transcriptional responses of heat shock protein 20 in the marine diatom Ditylum brightwellii exposed to metals and endocrine-disrupting chemicals. Environ. Toxicol. 2014, 29, 1379-1389. [CrossRef] [PubMed]

80. Lei, Q.N.; Wu, Y.Y.; Liang, H.Y.; Wang, Z.X.; Zheng, Z.; Deng, Y.W. Molecular cloning and expression analysis of heat shock protein 20 (HSP20) from the pearl oyster Pinctada martensii. Genet. Mol. Res. 2016, 15, gmr.15028799. [CrossRef] [PubMed]

81. Rhee, J.-S.; Raisuddin, S.; Lee, K.-W.; Seo, J.-S.; Ki, J.-S.; Kim, I.-C.; Park, H.G.; Lee, J.-S. Heat shock protein (Hsp) gene responses of the intertidal copepod Tigriopus japonicus to environmental toxicants. Comp. Biochem. Physiol. Part C Toxicol. Pharmacol. 2009, 149, 104-112. [CrossRef]

82. Rhee, J.S.; Kim, R.O.; Choi, H.G.; Lee, J.; Lee, Y.M.; Lee, J.S. Molecular and biochemical modulation of heat shock protein 20 (Hsp20) gene by temperature stress and hydrogen peroxide $\left(\mathrm{H}_{2} \mathrm{O}_{2}\right)$ in the monogonont rotifer, Brachionus sp. Comp. Biochem. Physiol. Part C Toxicol. Pharmacol. 2011, 154, 19-27. [CrossRef]

83. Shen, Y.; Gu, J.; Huang, L.; Zheng, S.; Liu, L.; Xu, W.; Feng, Q.; Kang, L. Cloning and expression analysis of six small heat shock protein genes in the common cutworm, Spodoptera litura. J. Insect Physiol. 2011, 57, 908-914. [CrossRef]

84. Leadbeater, B.S.; Karpov, S.A. Cyst formation in a freshwater strain of the choanoflagellate Desmarella moniliformis Kent. J. Eukaryot. Microbiol. 2000, 47, 433-439. [CrossRef]

85. Kristensen, T.N.; Dahlgaard, J.; Loeschcke, V. Inbreeding affects Hsp70 expression in two species of Drosophila even at benign temperatures. Evol. Ecol. Res. 2002, 4, 1209-1216.

86. Pedersen, K.S.; Kristensen, T.N.; Loeschcke, V. Effects of inbreeding and rate of inbreeding in Drosophila melanogaster-Hsp70 expression and fitness. J. Evol. Biol. 2005, 18, 756-762. [CrossRef] [PubMed]

87. Wheeler, J.C.; King, V.; Tower, J. Sequence requirements for upregulating expression of Drosophila hsp70 transgenes during aging. Neurobiol. Aging 1999, 20, 545-553. [CrossRef]

88. Trotter, E.W.; Kao, C.M.F.; Berenfeld, L.; Botstein, D.; Petsko, G.A.; Gray, J.V. Misfolded proteins are competent to mediate a subset of the responses to heat shock in Saccharomyces cerevisiae. J. Biol. Chem. 2002, 277, 44817-44825. [CrossRef]

89. Zhao, Q.; Wang, J.; Levichkin, I.V.; Stasinopoulos, S.; Ryan, M.T.; Hoogenraad, N.J. A mitochondrial specific stress response in mammalian cells. EMBO J. 2002, 21, 4411-4419. [CrossRef]

90. Giebel, L.B.; Dworniczak, B.P.; Bautz, E.K.F. Developmental regulation of a constitutively expressed mouse mRNA encoding a 72-kDa heat shock-like protein. Dev. Boil. 1988, 125, 200-207. [CrossRef]

91. Gunter, H.M.; Degnan, B.M. Developmental expression of Hsp90, Hsp70 and HSF during morphogenesis in the vetigastropod Haliotis asinina. Dev. Genes Evol. 2007, 217, 603-612. [CrossRef]

92. Cadman, C.S.; Toorop, P.E.; Hilhorst, H.W.; Finch-Savage, W.E. Gene expression profiles of Arabidopsis Cvi seeds during dormancy cycling indicate a common underlying dormancy control mechanism. Plant J. 2006, 46, 805-822. [CrossRef]

93. Chibani, K.; Ali-Rachedi, S.; Job, C.; Job, D.; Jullien, M.; Grappin, P. Proteomic analysis of seed dormancy in Arabidopsis. Plant Physiol. 2006, 142, 1493-1510. [CrossRef]

94. Lin, S.; Zhang, H.; Zhuang, Y.; Tran, B.; Gill, J. Spliced leader-based metatranscriptomic analyses lead to recognition of hidden genomic features in dinoflagellates. Proc. Natl. Acad. Sci. USA 2010, 107, 20033-20038. [CrossRef]

95. Wisecaver, J.H.; Hackett, J.D. Dinoflagellate genome evolution. Annu. Rev. Microbiol. 2011, 65, 369-387. [CrossRef] [PubMed]

Publisher's Note: MDPI stays neutral with regard to jurisdictional claims in published maps and institutional affiliations.

(C) 2020 by the authors. Licensee MDPI, Basel, Switzerland. This article is an open access article distributed under the terms and conditions of the Creative Commons Attribution (CC BY) license (http://creativecommons.org/licenses/by/4.0/). 